\title{
Cranio-thoracic bullet migration over a period of 27 years: case report
}

\author{
C. Castillo-Rangel; G. Reyes-Soto y R. Mendizábal-Guerra
}

Department of Neurosurgery. Hospital Juarez de México

\section{Summary}

We report the case of a 36 year old woman that was hurt in the head with a lost bullet while walking through the street when she was 9 years old. On admission, the patient was fully conscious with no neurological deficits. Skull radiography showed the intracranial bullet but she was dispatched after 24 hours of observation without neurological deterioration. Six months later she suddenly presented quadriplegia and after one year of rehabilitation she recovered the mobility and strength in all her limbs. 25 years latter she began with thoracic pain (dermatomal sensory changes), constipation, paresthesias and weakness in the lower extremities; the $X$-Ray showed a bullet caliber $9 \mathrm{~mm}$ in the thoracic canal at $\mathrm{T} 4$ level. The bullet was removed via posterior laminectomy and dorsal midline mielotomy. 12 hours after surgery, the patient presented signs of medullar shock. The post-operatory MRI showed the trajectory of the bullet through the brain to the spinal cord in FLAIR, and spinal cord edema as well. The patient received steroids as treatment for the spinal cord edema, and with the help of rehabilitation she recovered movement in the lower extremities 30 days after the surgery.

KEY WORDS: Thoracic canal. Quadriplegia. Laminectomy. Bullet. Migration.

Migración craneo-torácica de una bala: descripción de un caso

\section{Resumen}

Presentamos el caso de una mujer de 36 años de edad, que resultó herida en la cabeza con una bala perdida mientras caminaba a través de la calle cuando tenía 9 años de edad. Ingresó en otro hospital consciente y sin déficit neurológico. La radiografía de cráneo

Recibido: 10-11-09. Aceptado: 26-04-10. mostró una bala intracraneal, pero se envió a su domicilio después de $\mathbf{2 4}$ horas de observación sin deterioro neurológico. Seis meses más tarde presentó quadriplejía de forma súbita. Después de un año de rehabilitación recuperó la movilidad y fuerza en sus miembros inferiores. Tras 25 años comenzó con dolor torácico (cambios sensoriales), estreñimiento, parestesias y debilidad en las extremidades inferiores; las radiografías simples de tórax mostraron una bala a nivel T4. La bala fue extirpada mediante laminectomía posterior y mielotomía dorsal de línea media. Doce horas después de la cirugía, el paciente presentó signos de shock medular. La resonancia magnética de cráneo mostró la trayectoria de la bala a través del cerebro a la médula espinal mediante FLAIR. Después de la operación la paciente continuó con esteroides y rehabilitación, recuperando la movilidad de los miembros inferiores, treinta días después de la cirugía.

PALABRAS CLAVE: Canal torácico. Quadriplejía. Laminectomía. Bala. Migración.

Introduction

Penetrating head injuries are becoming increasingly common as a result of the widespread availability of firearms. Civilian penetrating head injury is a leading cause of morbidity and mortality and represents a significant public health problem. The severity of the injury is related to several factors, including velocity of the bullet, refraction of a bullet after hitting a hard structure, distance of flight, caliber, and trajectory of passage through the cranium, expressiveness of the damaged brain, vascular injury and bullet migration ${ }^{1-3,6,8,10,14,18,20-23,25}$. This last factor has been noted previously by other authors in the medical literature in the last 30 years. They reported bullet migration from intracranial structures to the spinal canal or from the cervical canal to the lumbar canal.

We have found no report of migration's bullet from cranium to thoracic spinal cord over a period of 27 years sustained by MRI. 


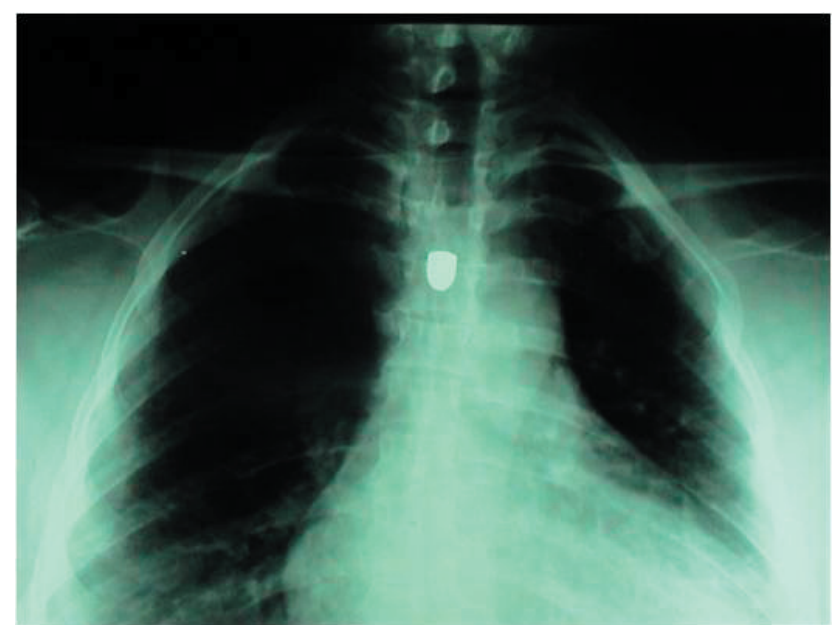

Figure 1. The X-Ray showed a bullet inside the thoracic canal at T4 level.

\section{Case report}

A 36-years old female was admitted to the Department of Neurosurgery at the Hospital Juárez de México. Patient had a history of injury in the head with a lost bullet while walking through the street when she was 9-years old. She was carried to a community clinic. The patient didn't lose consciousness and she had no neurological deficit. Physical examination revealed a single entry wound in the frontal bone, and no exit wound was found. The cranium X-ray showed a bullet caliber $9 \mathrm{~mm}$ apparently between both cerebral hemispheres and she was discharged of the hospital 24 hours after observation without neurological deficit. Six months later she suddenly presented quadriplegia. She was admitted to the emergency room and the neurological exam revealed a flaccid quadriplegia, paresthesias and alterations in vibration sense. She recovered the mobility and strength with rehabilitation one year after. 25 years later she began with thoracic pain (T4 dermatomal sensory changes), constipation, paresthesias and weakness in the lower extremities; the X-Ray showed a bullet inside the thoracic canal at T4 level (Figure. 1). The patient was subsequently admitted in our Hospital and was treated with intra venous steroids, antineuritic drugs and analgesics. Roentgenographic study included X-ray and CT locating the bullet at T4 level ( Figure. 2), occupying almost all the thoracic canal. A posterior T4 laminectomy and T3 and T5 hemilaminectomy was performed to remove the bullet. We didn't observed transmitted dural pulsation and after opening the dural membranes, the spinal cord was surrounding the bullet. A posterior mielotomy was made (Figure. 3), observing the bullet adhered to the spinal cord and using microdisection technique it was removed. 12 hours after surgery, the patient showed signs of medullary shock that was medically managed. The pos-operatory MRI showed the trajectory of the bullet through the brain to the
2010; 21: A-B

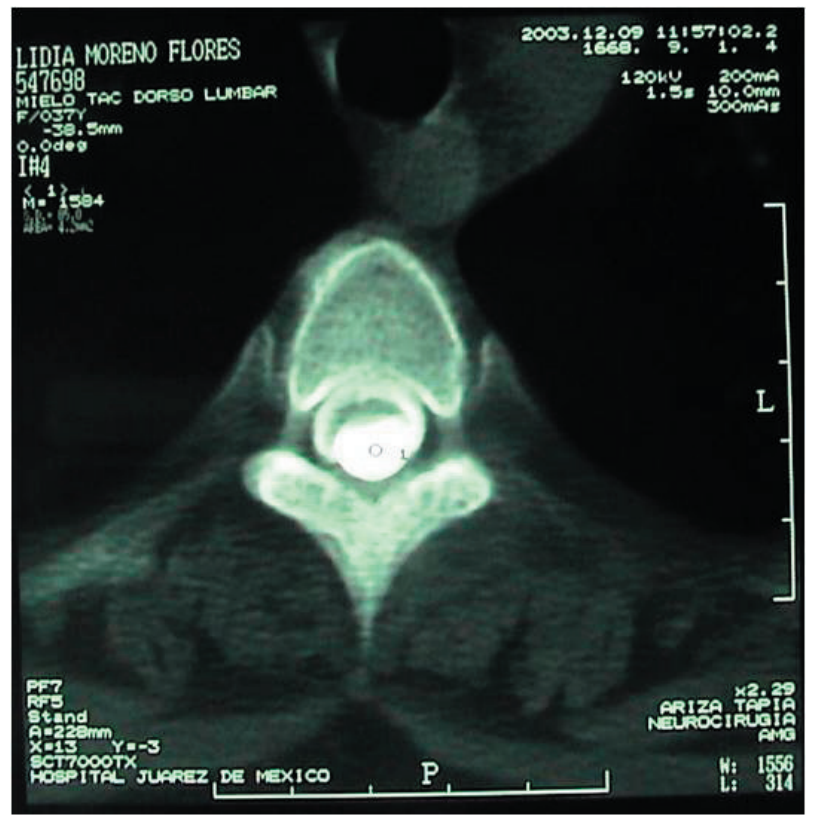

Figure 2. Mielotomography showing a foreign body displacing the spinal cord at level T4.

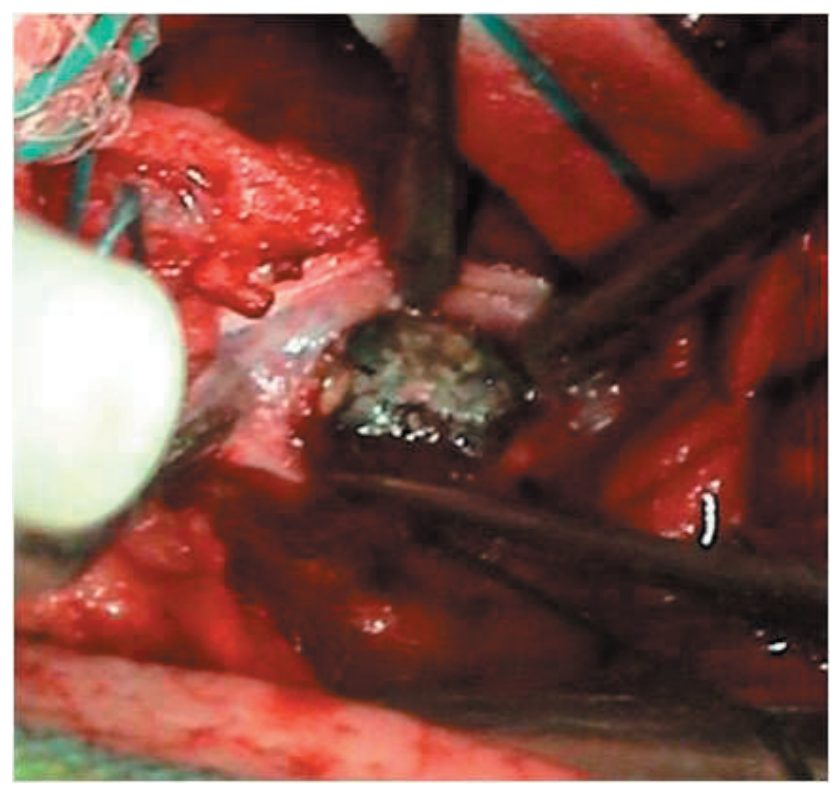

Figure 3. Intraoperative photograph showing the posterior mielotomy and the bullet adherent to the spinal cord.

spinal cord (Figure. 4). The patient received rehabilitation after surgery and recovered the movement in the lower extremities 30 days after the surgery. At last revision 6 months after the operation, the patient has improved her strength of the legs and she is able to walk with crutches.

\section{Discussion}

Many cases of bullet migration have been reported in 


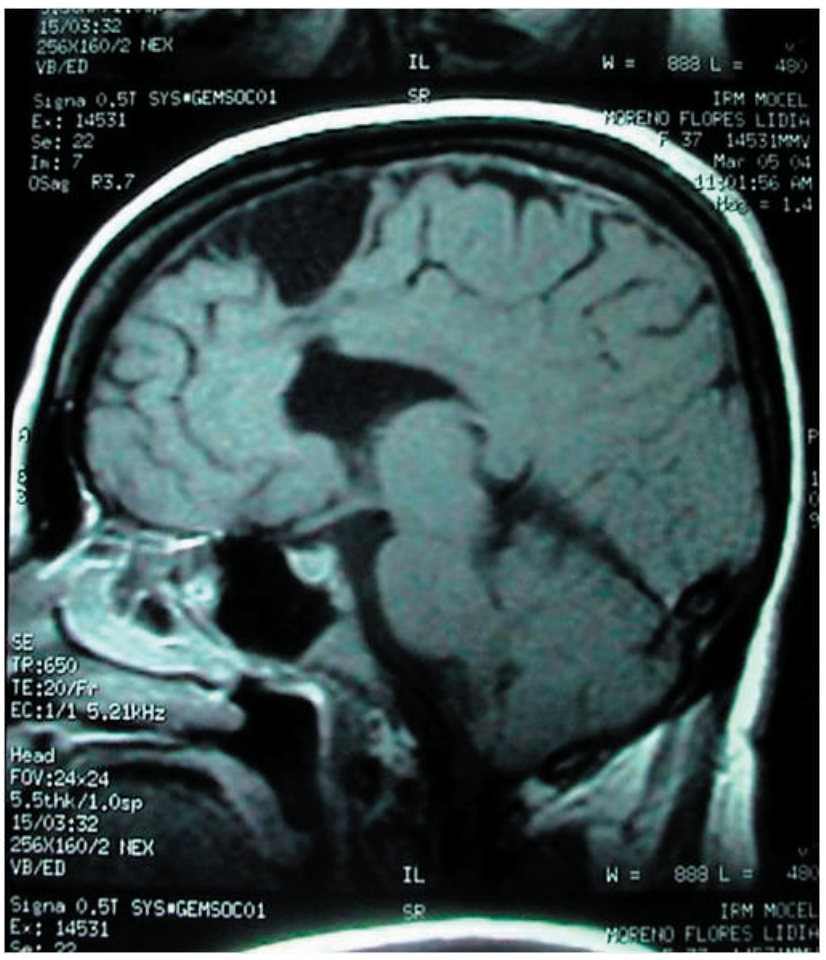

Figure 4. Cranial MR showing the trajectory of the bullet. through the brain to the spinal cord.

the nervous system, as well in the thoracic and abdominal cavity, including biliary tract and urinary tract ${ }^{5,17,19}$. In 1916, Vilvandre et al described two patients in whom movement and rotation of a bullet could be demonstrated on plain skull x-rays. 26 An injury by rifle bullet was reported by Jefferson, where the removal of the bullet was followed by a full recovery without complications ${ }^{9}$. In 1942, Campbell et al., reported the movement of an intraventricular bullet within the left lateral ventricle of a 29-year-old woman who was struck accidentally by a deer slug ${ }^{4}$. In 1967, Lang reported a patient in whom an intraventricular bullet had migrated to the level of the aqueduct of Sylvius, producing acute hydrocephalus ${ }^{13}$. Our case shows the migration of an entire bullet without fragments, from the intracranial compartment to the thoracic canal over period of 27 years. The MRI demonstrated the entire trajectory that the bullet went through. Proposed mechanisms of migration include gravity, motion of the spine, and physiologic cerebrospinal fluid circulation ${ }^{4,7,11,13,24,27}$. In this case the bullet followed the cerebrospinal fluid circulation, through the ventricles, then apparently the bullet continues parallel to the four ventricle, sylvian aqueduct and ependimal canal. However the patient never had signs of hydrocephalus. The anterior migration of the bullet explains the clinic quadriplegia, when it passed parallel to sylvian aqueduct. This kind of migration has been attributed to cerebral softening secondary to edema and local tissue damage, the specific gravity of the bullet (which greatly exceeds that of cerebral tissue), and gravitational factors ${ }^{27}$. It is difficult to say whether ventricular pulsations contribute to the migration of intracerebral bullets. Bullets that do not move within the brain or become fixed in location after initial movement are presumably walled off by gliosis and fibrotic scarring. These processes usually take from weeks to several years to develop ( 27 years in our case); When bullets lie free within the cerebrospinal fluid cavities, they are capable of migrating to distant parts of the brain and spinal canal $1^{7,11-13,16,17}$.

\section{Conclusion}

We present a case report which have the highest documented level of penetration from a frontal head injury with migration within the ventricular system to the cervical spinal canal to T-4 over a period of 27 years with progression of neurologic deficits. We correlate MRI images that show the trajectory of the bullet through the brain and spinal cord. We have not found report of bullet migration from a penetrating head injury to the thoracic spinal canal.

\section{References}

1. Alessi, G., Aiyer, S., Nathoo N.: Home-made gun injury: spontaneous version and anterior migration of bullet. Br Journal of Neurosurgery 2002; 16: 381-384.

2. Allen, I., Scott, R., Tannel, J.: Experimental high velocity head injury. Injury 1982; 14: 183-193.

3. Brent, D., Perper, J., Allman, C.: Alcohol firearms, and suicide among youth: Temporal trend in Allegheny County, Pennsylvania. JAMA 1987; 257: 3369-3372.

4. Campbell, E., Howard, WP., Weary, WB.: Gunshot wounds of the brain. Report of two unusual complications: Bifrontal pneumocephalus and loose bullet in the lateral ventricle. Arch Surg 1944; 44: 789-798.

5. Filosso, PL., Donati, G., Agaccio, G.: Mancuso M. Distant endoarterial bullet migration following penetrating chest injury. Eur J Cardio-Thoracic Surg 2003; 23: 242.

6. Fujimoto, Y., Cabrera, HT., Pahl, FH., D’Andrade, AF., Marino, JR.: Spontaneous migration of a bullet in the cerebellum-case report. Neurologia Medico-Chirurgica 2001; 41: 499-501.

7. Furlow, LT., Bender, MB., Teuber, HL.: Movable foreign body within the cerebral ventricle. A case report. J Neurosurg 1947; 4: 380-386.

8. Jagger, J., Dietz, P.: Death and injury by firearms: Who cares? JAMA 1986; 255: 3143-3144.

9. Jefferson, G.: Removal of a rifle bullet from the right lobe of the cerebellum: Illustrating the spontaneous movement of a bullet in the brain. Br J Surg 1918; 5: 422-424.

10. Kaufman H: Civilian gunshot wounds to the head. Neurosurgery 1993; 32: 962-964. 
Cranio-thoracic bullet migration over a period of 27 years: case report

11. Kellhammer, G.: Geshosswanderung in Ventrikelsystem. Zentralbi Chir 1939; 66: 1775-1779.

12. Kerin, D.S., Fox, R., Mehringer, M., Grinnel, V., Miller, R.E., Hieshima, G.B.: Spontaneous migration of a bullet in the central nervous system. Surg Neurol 1997; 20: 301-304.

13. Lang, E.K.: Acute hydrocephalus secondary to occlusion of the aqueduct by a bullet. J La State Med Soc 1969; 121 : 167-169.

14. Lillard, P.: Five years experience with penetrating craniocerebral gunshot wounds. Surg Neurol 1978; 9: 79-83.

15. Milhorat, T.: Cerebrospinal fluid as reflection of internal milieu of brain. New York, in Wood JH (ed): Neurobiology of Cerebrospinal Fluid 2. Plenum Publishing, 1983, pp 1-23.

16. Milhorat, T.H.: The third circulation revisited. J Neurosurg 1975; 42: 628-645.

17. Miller, J.T., Scheidler, M.G., Miller, R.. Rodriguez, A.: Cystoscopic removal of a large-caliber bullet from the left ureter: a case report of missile migration after a gunshot wound. Journal of Trauma-Injury Infection \& Critical Care 2004; 56: 1141-1143.

18. Pacio, C.I., Murphy, M.A.: BB embolus causing monocular blindness in a 9-year-old boy. Am J Ophthalmology 2002; 134: 776-778.

19. Raghavendran, K., Evans, J.T.: Bullet migration within the inferior vena cava. Southern Medical Journal 2003; 96: 96-98.

20. Saunders, M.S., Cropp, A.J., Awad, M.: Spontaneous
Neurocirugía

2010; 21: 326-329

endobronchial erosion and expectoration of a retained intrathoracic bullet: case report. J Trauma 1992; 33: 909-911.

21. Schick, U., Hassler, W.: Late hydrocephalus in a case of wandering bullet into the pineal region. Acta Neurochirurgica 2003; 145: 79-81.

22. Selden, B.: Craniocerebral wound ballistics. Indiana Med 1987; 80: 150-152.

23. Sights, W. Jr.: Ballistic analysis of shotgun injuries to the central nervous system. J Neurosurg 1969; 31: 25-33.

24. Small, J.M.: Retained intraventricular foreign body. $\mathrm{Br}$ J Surg 1945; 32: 414-418.

25. Van Way, C.W.: Intrathoracic and intravascular migratory foreign body. Surg Clin North Am 1989; 69: 125-133.

26. Vilvandré, G., Morgan, J.D.: Movements of foreign bodies in the brain. Arch Radiology Electrotherapy 1916; 21: 22-27.

27. Wasserman, S.M., Cohen, J.A.: Spontaneous migration of an intracranial bullet fragment. Mt Sinai J Med (NY) 1979; 46: 512-515.

Castillo-Rangel, C.; Reyes-Soto, G.; Mendizábal-Guerra, R.: Cranio-thoracic bullet migration over a period of 27 years: case report. Neurocirugía 2101; 21: 326-329.

Correspondace: Carlos Castillo-Rangel M.D. Department of Neurosurgery. Hospital Juarez de México. Avenida Instituto Politécnico Nacional 5160. Colonia: Magdalena de las salinas. Delegación: Gustavo A. Madero. Zip: 07760 Distrito Federal. 